\title{
Chinese College Students' English Reading Comprehension in Silent and Loud Reading-Mode
}

\author{
Yan Jiang ${ }^{1}$ \\ ${ }^{1}$ School of Foreign Languages, China West Normal University, Nanchong, China \\ Correspondence: Yan Jiang, School of Foreign Language, China West Normal University, No.1 ShiDa Road, \\ 637009 Nanchong, Sichuan, China. Tel: 86-137-7818-9933. E-mail: luckypig924@163.com
}

Received: December 16, 2014 Accepted: January 20, 2015 Online Published: March 25, 2015

doi:10.5539/elt.v8n4p24 URL: http://dx.doi.org/10.5539/elt.v8n4p24

\begin{abstract}
In language teaching, emphasis is usually placed on students' reading comprehension, because reading comprehension remains one of the main important factors for their English language learning. Research shows, however, that reading comprehension is a sophisticated process and many students have met difficulties in constructing meaning from writing context. This current study, by comparing silent reading mode and loud reading mode, attempts to find out their respective effects on Chinese college students' reading comprehension. There was a 16-week experiment on 29 sophomores, who were divided into experimental and control groups. Data were elicited through conventional process of language experiment. Besides these quantitative data, an interview was designed to collect students' attitudes and opinions as qualitative data. All the results indicate that silent reading-mode significantly improves participants' reading comprehension while aloud reading-mode does not reveal the same findings.
\end{abstract}

Keywords: Chinese college students, reading comprehension, silent reading-mode, loud reading-mode

\section{Introduction}

Among the academic domains reading has always been the core in systematic research of English teaching and learning (L. Fuchs \& D. Fuchs, 2006), because students require information and concepts through the process of reading comprehension. Thus, students who display poor reading skills are more likely to encounter difficulties in many academic areas, such as English learning. For foreign language learners, reading is one of the most important skills to learn, which can advance learners to build their vocabulary and establish their enduring learning and improvement in language learning. According to Ahmadi and Hairul (2012), reading comprehension exists as an important factor in EFL learning process and people should pay enough attention to reading at different levels. Many students in China have major difficulties with English reading comprehension even after years of learning the English language. Therefore, reading research has long been interested in various aspects that affect reading comprehension, such as in reading modes.

\section{Silent Reading-Mode and Aloud Reading-Mode}

Research, however, in the area of the functions and applications of reading modes (e.g. silent, aloud) during reading process has provided mixed results (Juel \& Holmes, 1981; McCallum, Sharp, Bell, \& George, 2004), which systematically demonstrate that these two reading modes may influence comprehension in totally different ways (Jones \& Lockhart, 1919; Juel \& Holmes, 1981). All the researches could be divided into three categories.

On the one hand, some researchers have admitted that individuals can gain more information when reading silently than in a loud way (Pinter, 1913; Mead, 1915, 1917; Jones \& Lockhart, 1919). And they find the answer to explain this phenomenon that during the reading process readers' limited resources has to be distributed to more aspects, such as pronunciation, intonation, structure of words, even the division of paragraphs. Therefore, the restricted cognitive resources of the readers are greatly reduced because of their own voice interference (Jones \& Lockhart, 1919). In 1981, Juel \&Holmes also mention that reading aloud may adhere to a "bottom up" process, which means that readers' decoding capacity seems to halt at the same time as they achieve phonological recording in aloud reading. In other words, when the reading process stops directly after achieving phonological recordings, then lexical access or comprehension processes may never occur. Since less proficient readers could not get automatic comprehensive skills, they may become more likely to only focus on 
phonological recordings, while partly ignoring the key step to comprehend the meaning of the text.

On the other hand, other researchers have got new results: reading aloud, when compared to reading silently, can help readers to comprehend more details of the reading materials (Duffy \& Durrell, 1935; Collins, 1961; Rowell, 1976). When talking about their findings that comprehension is enhanced in a loud reading mode, they have found a new explanation that only poor readers may benefit more than good readers from the experience of hearing themselves read and from the required concentrated attention needed to read aloud, but skilled readers may not share the same benefits (Kragler, 1995; Swalm, 1973).

In addition, there are some researchers (Jones, 1932; Poulton \& Brown, 1967; McCallum et al., 2004) who have shown an indifferent attitude for reading mode researches, because they find there exists no obvious difference in the comprehension after reading silently while compared to reading aloud.

Evidence also exists indicating that because of the various reading proficiency of the readers, the effects of oral and silent reading on comprehension may be presented differently. For example, Kragler (1995) finds that reading aloud seems more effective to beginning readers than silent reading; Miller and Smith (1990) also establish a link between comprehension scores and readers' proficiency by the conclusion that less skilled readers have gained more scores in comprehension examination when they read out the passages; average readers have higher scores when they choose to read the passages in a silent way; proficient readers demonstrate no remarkable differences in comprehension no matter which reading mode is applied.

\section{The Study Design}

\subsection{Study Question}

The primary purpose of the current study was to explore the relationship among oral reading mode, silent reading mode, English reading comprehension, and English achievement in Chinese English college students, to determine if their English comprehension and achievement were systematically affected by reading mode.

\subsection{Participants and Study Process}

29 participants (6 males and 23 females) were recruited from China West Normal University. They were sophomores from the same class in the department of Chinese language and Literature, all of whom had passed the CET-4, which was an important reason for them to be chosen into this study. 29 students were voluntary to participate in the study. At the beginning of the study, 29 students were divided at random into experimental group ( 2 males and 13 females) and control group (4 males and 10 females).

Every morning and evening they were assigned the same articles to finish in the same given time (20 minutes every time). The only difference lay in the different reading mode: students in experimental group read the articles in a silent way while students in control group read them aloud.

At the end of one semester (16 weeks), two groups had attended the Standard English Competence Test. The test paper was Test for English Major Grade 4 in 2008, including dictation (15\%), listening comprehension (15\%), cloze $(10 \%)$, grammar and vocabulary $(15 \%)$, reading comprehension $(20 \%)$ and writing $(25 \%)$. Additionally, to guarantee the study's reliability, all the papers were reviewed by two professors in another university, whose average score was the final result of the participants.

\subsection{Choice of Reading Articles}

32 reading articles were chosen from "Reading comprehension" part in the papers of the CET-4. Every week two articles were assigned to the participants. Except for four narrative stories, other passages were academic ones.

\subsection{Data Collected}

Before the study, the experimental group and control group were pre-tested. After the study was conducted, the two groups were post-tested as to analyze whether there were significant differences in every aspect of English learning and English competence. In the present study descriptive and statistical analysis were conducted through the computer software program SPSS. Descriptive analysis involved the mean score of both the pre-test and post-test results. The statistical analysis included a paired-sample t-test to compare scores on the pre-test and post-test. At the meantime, Kuder-Richardson 21 was used to test the credibility of all the results. At last, ANOVA was employed to test participants' English performance in experimental group. After descriptive and statistical data were collected, an interview for 29 students was underway to get qualitative information to support the previous results from the quantitative research. 


\section{Data Analysis}

\subsection{Descriptive Analysis}

Table 1. Control group's analysis

\begin{tabular}{lll}
\hline Control group & Pre-test & Post-test \\
\hline Mean & 50.3421 & 65.8643 \\
Median & 50.0000 & 66.0000 \\
Std. Deviation & 5.3374 & 3.6543 \\
Range & 19.00 & 11.00 \\
Skewness & .356 & .162 \\
Kurtosis & -.750 & -.487 \\
\hline
\end{tabular}

Table 1 shows that before this study, the mean of control group was 50.34, but after the study, the mean increased to 65.86; the pre-test Std. Deviation was 5.337 and the post-test Std. Deviation decreased to 3.654; the range changed from 19.00 to 11.00; and there appeared a good normal situation on Skewness and Kurtosis. All the evidence explained that 16-week English learning in loud reading-mode had a certain effect on students' English achievement.

Table 2 revealed the big change in mean in experimental group from 50.25 to 82.76 ; Std. Deviation decreased from 6.479 to 5.574; the range significantly reduced to 19.00 , and Skewness transformed from negative to positive, which indicated the results was closer to normal distribution. What can be concluded was that 16-week English learning in silent reading-mode greatly improved participants' English achievement.

Table 2. Experimental group's analysis

\begin{tabular}{lll}
\hline Experimental group & Pre-test & Post-test \\
\hline Mean & 50.2453 & 82.7584 \\
Median & 50.0000 & 83.0000 \\
Std. Deviation & 6.4790 & 5.5748 \\
Range & 25.00 & 19.00 \\
Skewness & -.382 & .074 \\
Kurtosis & -.611 & -.772 \\
\hline
\end{tabular}

\subsection{Statistical Analysis}

4.2.1 Two Groups' Difference in English Competence before the Study

Table 3. Two groups' statistical comparison (Pre-test)

\begin{tabular}{llll}
\hline Group & Mean & Std. Deviation & Std. Error Mean \\
\hline Experimental & 50.2453 & 6.4790 & 1.77841 \\
Control & 50.3421 & 5.3374 & 1.5478 \\
\hline
\end{tabular}

Based on the comparison from Table 3, these intuitive statistics showed there was no obvious difference between two groups before the study. In order to get more objective outcome, Table 4 carried out a detailed inspection. 
Table 4. Independent sample test

\begin{tabular}{|c|c|c|c|c|c|c|c|c|}
\hline & & \multicolumn{7}{|c|}{$\begin{array}{l}\text { Levene's Test for } \\
\text { Equality of Variance }\end{array}$} \\
\hline & & \multirow[t]{2}{*}{$\mathrm{F}$} & \multirow[t]{2}{*}{ Sig. } & \multirow[t]{2}{*}{$\mathrm{t}$} & \multirow[t]{2}{*}{$\mathrm{df}$} & \multirow{2}{*}{$\begin{array}{l}\text { Sig } \\
\text { (2-tailed) }\end{array}$} & \multicolumn{2}{|c|}{$\begin{array}{l}95 \% \text { Confidence Interval } \\
\text { of the Difference }\end{array}$} \\
\hline & & & & & & & Lower & Upper \\
\hline \multirow{2}{*}{ Pre-test } & $\begin{array}{l}\text { Equal variances } \\
\text { assumed }\end{array}$ & .088 & .758 & -.433 & 26 & .665 & -5.45361 & 3.7658 \\
\hline & $\begin{array}{l}\text { Equal variance } \\
\text { not assumed }\end{array}$ & & & -.435 & 25.763 & .663 & -5.42343 & 3.6598 \\
\hline
\end{tabular}

In Table 4, according to Levene's Test for Equality of Variance, $\mathrm{F}=0.088$, Sig. $=0.758$, there was a hypothesis that these two groups had no significant difference. Thus, in t-test the data under the assumed equal variances were chosen and its sig. (2-tailed) $=0.665$, which certified the correctness of the previous hypothesis: English competence of the experimental group and control group was close.

4.2.2 Two Groups' Difference in English Competence after the Study

Table 5. Two groups' statistical comparison (Post-test)

\begin{tabular}{llll}
\hline Group & Mean & Std. Deviation & Std. Error Mean \\
\hline Experimental & 83.0000 & 5.5748 & 1.45352 \\
Control & 66.0000 & 3.6543 & .87964 \\
\hline
\end{tabular}

From Table 5's simple description, it was easy to find that two groups had significant difference after the study. Then in Table 6 there were more evidence to be found to demonstrate such a difference.

Table 6. Independent sample test

\begin{tabular}{|c|c|c|c|c|c|c|c|c|}
\hline & & \multicolumn{7}{|c|}{$\begin{array}{l}\text { Levene's Test for } \\
\text { Equality of Variance }\end{array}$} \\
\hline & & \multirow[t]{2}{*}{$\mathrm{F}$} & \multirow[t]{2}{*}{ Sig. } & \multirow[t]{2}{*}{$\mathrm{t}$} & \multirow[t]{2}{*}{$\mathrm{df}$} & \multirow{2}{*}{$\begin{array}{l}\text { Sig } \\
\text { (2-tailed) }\end{array}$} & \multicolumn{2}{|c|}{$\begin{array}{l}95 \% \text { Confidence Interval } \\
\text { of the Difference }\end{array}$} \\
\hline & & & & & & & Lower & Upper \\
\hline \multirow{2}{*}{ Pre-test } & $\begin{array}{l}\text { Equal variances } \\
\text { assumed }\end{array}$ & 3.321 & .065 & 10.454 & 27 & .000 & 15.96454 & 22.54367 \\
\hline & $\begin{array}{l}\text { Equal variance } \\
\text { not assumed }\end{array}$ & & & 10.987 & 21.98 & .000 & 15.23125 & 22.56312 \\
\hline
\end{tabular}

The conclusion can be drawn that although students in experimental group and control group had learnt English in the same classroom at the same time, listened to the same teacher's instruction and shared the same learning resources, the only difference between two groups was the different reading-mode they had employed in their spare time. Therefore, silent reading-mode seemed to be served to promote students' English competence better than loud reading-mode.

\subsection{ANOVA Analysis and Paired Sample Statistics}

Because the test paper for participants was Test for English Major Grade 4 in 2008, including grammar 1) vocabulary 2) reading comprehension 3) listening comprehension 4) and writing 5) the current study used Analysis of Variance (ANOVA) to test these 5 items in English paper with the purpose to compare the achievement between the experimental group and the control group after 16-week study in different reading modes. 
Table 7. ANOVA analysis

\begin{tabular}{llll}
\hline Post-test between groups & Mean Square & F & Sig. \\
\hline 1 & 1.865 & .908 & .342 \\
2 & 37.943 & 27.065 & .000 \\
3 & 650.321 & 83.765 & .000 \\
4 & 68.798 & 24.743 & .000 \\
5 & 135.543 & 38.642 & .000 \\
\hline
\end{tabular}

Except the first item (grammar)'s Sig. was larger than 0.05, other 4 items (vocabulary, reading comprehension, listening comprehension and writing)'Sig. was smaller than 0.05 . The finding showed that the students of experimental group who had been instructed silent reading-mode made more demonstrable progress than those of control group with loud reading-mode.

To further inspect the detailed changes in experimental group, the study employed a Paired-sample test to compare means in every item before and after the study. Table 8 showed that all the means were negative and the significance of their difference was obvious (Sig. (2-tailed) $=0.000$, far less than 0.05), which proved that silent reading mode indeed had improved many aspects in students' English learning, especially in vocabulary, reading comprehension, listening comprehension and writing.

Table 8. Paired samples test

\begin{tabular}{llllll}
\hline \multirow{2}{*}{ Experimental group } & \multicolumn{2}{l}{ Paired Difference } \\
\cline { 2 - 6 } & Mean & Std.Deviation & Std. Error Mean & $\mathrm{t}$ & Sig(2-tailed) \\
\hline Pre1-Post1 & -3.00000 & 1.87876 & .47657 & -6.123 & .000 \\
Pre2-Post2 & -4.67532 & 1.23908 & .33243 & -14.000 & .000 \\
Pre3-Post3 & -11.23224 & 2.87687 & .77431 & -14.450 & .000 \\
Pre4-Post4 & -7.0000 & 1.88769 & .48642 & -14.453 & .000 \\
Pre5-Post5 & -6.7000 & 1.85676 & .48003 & -14.168 & .000 \\
\hline
\end{tabular}

\subsection{Interviews with the Participants}

There are two questions in the interviews to demonstrate students' attitude and insights about silent reading mode and loud reading mode:

1) Which reading mode seems more suitable for your English learning?

2) What are the characteristics your reading mode present to you?

For the first question, 20 students $(68.97 \%)$ preferred silent to aloud reading mode, 4 students $(13.79 \%)$ chose aloud reading mode, 5 students (17.24\%) agreed that there did not exist a distinct difference between these two reading modes.

And the answers for second question could be concluded to the following statements. 20 students preferred silent reading mode because "silent reading mode gave me a space to think and time to catch useful information," "I was used to reading in silent way, as my middle-school teachers told me," "I could concentrate on reading, not worrying about my pronunciation or my tone," "when I read silently, I could quickly find the key points without reading the whole passage," "reading aloud, I tried my best to pronounce every single word correctly, so I always forgot to understand the meaning," "it usually spent me one more time finishing my comprehension when I read the article for the first time," "I felt shameful if someone noticed my errors during my reading the passages." 4 students endorsed loud reading mode because "reading aloud gave me a kind of confidence," and "reading in a loud way forced me to read word by word, sentence by sentence, so it became natural to get all the information important to the comprehension." At last, 5 students who did not show their preference to two reading modes admitted that "we had not noticed any differences" and "there should be their own pros and cons of two reading modes", but they could not give any meticulous explanations. 
Based on students' attitudes and opinions about two reading modes, it was not difficult to conclude that most students prefer to employ silent reading mode in their English learning, which has strongly supported, from a subjective point of view, the findings from the previous empirical study.

\section{Discussion}

Some previous researches prefer to loud reading mode, because reading comprehension competence can easily be measured by WCPM (words read correctly per minute), CBM (curriculum-based measurement) etc. When students read aloud, it can be guaranteed that the students indeed read the complete articles. Furthermore, in keeping with prescribed procedures for assessing WCPM or CBM, the experimenters re-direct students if they skip or repeat lines. With these instructions, therefore, the significantly higher level of comprehension may have been achieved. When students read silently, important information may not be identified, because when a student chooses not to read the article, experimenters could not detect his true reading behavior. So their reading comprehension competence does not seem to be the same as in the loud condition.

Other researchers, however, have carried out empirical experiment and proposed different ideas, which prove that reading aloud may create obstacles in comprehension because cognitive resources are being applied mainly to achieving phonological codes, as opposed to extracting meaning from the text. The present study also indicates that reading comprehension is enhanced when students read silently, as opposed to aloud.

Additionally, there are benefits with assessing students' reading competence under silent reading mode. Firstly, it is easier to carry out silent reading mode in big-class circumstances in China, which do not bother other students; secondly, most students are familiar with silent reading mode, because this mode has been reinforced since the beginning of English learning in middle-school; thirdly, through comparing two groups' performance in scientific ways, it is convenient to draw a conclusion that students in silent reading mode does greatly promote their English learning competence, not only in reading comprehension, but also in vocabulary, listening and writing.

However, the current study also puts forward some questions about how to objectively assess these two reading modes. The most outstanding one is the weak correlations between loud and silent reading modes, which suggest that these two reading modes may be taught as two distinct skills for college students: their advantages, disadvantages, application and distribution should be introduced in detail and in system. Future researches maybe include how to employ these two reading modes in different tasks at different periods of time.

There are also some limitations in this study that must be mentioned. The sample size is relatively small and 29 sophomores all come from the same department in one university. Because of the limited sample size, the generalizability of the results from this study is limited. The results may also have been influenced by the research procedures and instruments, such as the limited time, the chosen articles, teachers' instruction, etc. Finally, it is important to note that all the participants have passed the CET-4, which means their English proficiency is above the average level. The outcome, therefore, would be totally different if a more diverse population of students is selected.

\section{Conclusion}

Reading comprehension can be one of the most important parts for language learners to master and one of the most frequently mentioned topics for teachers to address in the classroom. But most of the students still have difficulty with constructing meaning from the written English texts.

The present study has been conducted in order to compare silent reading mode and loud reading mode in Chinese college students' English learning process. The objectives of the study were to find a more appropriate reading mode to promote students' English learning. The scientific findings revealed that silent reading mode was more suitable for proficient Chinese students in this study. Therefore, for pedagogical implication, the application of silent reading mode might offer better solutions to develop college students' English reading comprehension competence in China.

\section{References}

Ahmadi, M. R., \& Hairul, N. I. (2012). Reciprocal teaching as an important factor of improving reading comprehension. Journal of Studies inEducation, 2(4), 153-173.

Collin, R. (1961). The comprehension of prose material by college freshman when read silently and when read aloud. Journal of Education Research, 55, 79-82.

Duffy, G., \& Durrell, D. (1935-36). Third grade difficulties inoral reading. Education, 56, 37-40.

Fuchs, L. S., \& Fuchs, D. (2006). A framework for building capacity for responsiveness to intervention. School 
Psychology Review, 35, 621-626.

Jones, E. E. (1932). A comparison of comprehension results in oral and silent reading. Peabody Journal of Education, 9, 292-296.

Jones, E. E., \& Lockhart, A. V. (1919). A study of oral and silent reading in the elementary schools of Evanston. School and Society, 10, 587-590.

Juel, C., \& Holmes, B. (1981). Oral and silent reading of sentences. Reading Research Quarterly, 16, 545-568.

Kragler, S. (1995). The transition from oral to silent reading. Reading Psychology: An International Quarterly, 16, 395-408.

McCallum, R. S., Sharp, S., Bell, S. M., \& George, T. (2004). Silent versus oral reading comprehension. Psychology in the Schools, 41, 241-246.

Mead, C. D. (1915). Silent versus oral reading with one hundred sixth-grade children. The Journal of Educational Psychology, 6, 354-348.

Mead, C. D. (1917). Results in silent reading versus oral reading. Journal of Education Psychology, 8, 367-368.

Miller, S. D., \& Smith, D. E. P. (1990). Relationship among oral reading, silent reading and listening comprehension of students at different competency levels. Reading Research and Instruction, 29, 73-84.

Pinter, R. (1913). Oral and silent reading of fourth grade pupils. Journal of Educational Psychology, 4, 333-337.

Poulton, E. C., \& Brown, C. H. (1967). Memory after reading aloud and reading silently. British Journal of Psychology, 58, 219-222.

Rowell, E. H. (1976). Do elementary students read better orally or silently? The Reading Teacher, 29, 367-370.

Swalm, J. E. (1973). A comparison of oral reading, silent reading, and listening comprehension. Education, 92, 111-115.

\section{Copyrights}

Copyright for this article is retained by the author(s), with first publication rights granted to the journal.

This is an open-access article distributed under the terms and conditions of the Creative Commons Attribution license (http://creativecommons.org/licenses/by/3.0/). 